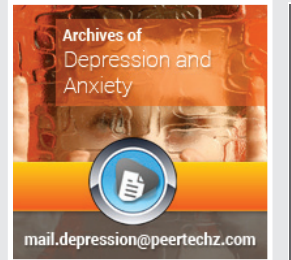

\title{
History of depression through the ages
}

\section{Michel Bourin*}

Neurobiology of anxiety and mood disorders, University of Nantes, 98, rue Joseph Blanchart 44100

Nantes, France

Received: 23 December, 2019

Accepted: 05 May, 2020

Published: 06 May, 2020

*Corresponding author: Michel Bourin, Neurobiology of anxiety and mood disorders, University of Nantes, 98, rue Joseph Blanchart 44100 Nantes, France,

E-mail:michel.bourin@univ-nantes.fr

Keywords: Depression; DSM; Freud; Greco-roman antiquity; Kraepelin

https://www.peertechz.com

\section{Check for updates}

\begin{abstract}
Depressive thoughts appeared from the origins of Humanity. They are found in philosophical writings and in literature since Antiquity. They have been approached in a religious or medical way since always, with conceptions which sometimes mixed physiological and mystical explanations. With the advent of psychiatry as a medical discipline, depressive disorder was included in the classifications of mental disorders. In the first half of the $20^{\text {th }}$ century, depression was only a detectable syndrome in most mental illnesses, psychoses and neuroses, and received no special attention in our societies. Its determinism is designed in a multifactorial way, integrating psychological, social and biological factors.
\end{abstract}

\section{Introduction}

Depression is often presented as a fashionable disease. It is considered to be the disease of the 21st century. Yet it was already described by Hippocrates in antiquity and it was at the beginning of the 1800 s that this term of depression, of the Latin "depressio" meaning depression, will make sense with the birth of psychiatry. From this distant period to the present day, it is possible to discover the long journey which is a fact of depression, a well-defined clinical entity. The aim of this article is to follow the concept of depression through the ages, from ancient times to the present day; to see how it was built.

\section{Greco-Roman antiquity}

Hippocrates Melancholy has been known since Antiquity and described as such: "If fear and sadness last a long time, such a state is melancholy," writes Hippocrates in his book Aphorisms [1]. Indeed, Hippocrates, a Greek physician, is considered the first physicist to describe melancholy or depression clinically. In the 5th century $\mathrm{BC}$, Hippocrates founded the theory of moods. According to this theory, the body contains four moods that each determines our temperament. The four moods are [2].

- blood: produced by the liver and received by the heart (blood type)

- the phlegm or phlegm or lymph attached to the brain (lymphatic character)
- yellow bile coming from the liver (bilious character, that is to say anxious)

- the black or atrabile bile coming from the spleen (melancholic character)

These moods correspond to the four elements themselves characterized by their own qualities:

- fire: hot and dry

- air: hot and humid

- the earth: cold and dry

- water: cold and wet

The sanguine, the one in whom blood predominates over other moods, is in a happy mood.

The phlegmatic (air) is said of the calm and imperturbable man who keeps his cold and almost apathetic.

The bilious (fire) is an inclined to anger.

The atrabilist is the one that a black bile makes sad and sorrowful.

The brain is the seat of "madness" and "delirium". He distinguishes: depression (melancholy), epilepsy (mania, agitation with fever) and delirium (phrenitis: acute delirium, feverishness). 
According to the physicist, when the seasons vary, this or that element predominates. In this way, physical and mental health is based on the balance of moods and the qualities that accompany them. Any minor imbalance causes "mood swings", any major imbalance threatens health. By example, autumn, dry and cold, promotes black bile and melancholy.

The notion of melancholy is therefore very old and holds its place within these four temperaments [3]. Until rebirth, melancholy (mêlas = noir and chole $=$ bile in Greek) will be considered as a disease caused by an excess of black bile in the body. We find this use in expressions like "to make bile" or "to make a blood of ink". The spleen is the organ responsible for this disorder (while current medicine sees the organ of immune defenses). Its psychic origin will be recognized only from the 18th century. It is especially to one of these disorders that Hippocrates is interested: the melancholy or "spleen" signifying the "spleen", "the bad mood". He inspired Baudelaire a French poet, who later wrote "the flowers of evil" by drawing his ideas from this theory [4], Figure 1.

$\begin{array}{lcccc}\text { Mood } & \text { Element } & \text { Season } & \text { Body } & \text { Temper } \\ \text { Blood } & \text { Air } & \text { Spring } & \text { Blood } & \text { Sanguine } \\ \text { Black Bile } & \text { Land } & \text { Summer } & \text { Spleen } & \text { Choleric } \\ \text { Yellow Bile } & \text { Fire } & \text { Fall } & \text { Liver } & \text { Melancholic } \\ \text { Phlegm } & \text { Water } & \text { Winter } & \text { Brain } & \text { Phlegmatic }\end{array}$

Figure 1: Summary table of the "four humors theory" according to Hippocrates, 5th century BC.

After the theory of the four moods which had its full development with Hippocrates at the end of the fifth century and beginning of the fourth century $\mathrm{BC}$ [5] and recovery then reinforced centuries later, including Galen, doctor and philosopher of the times that followed. Through the Middle Ages and the Renaissance, these people speculated on the four temperaments that result from these moods and their correspondence with the four ages of man. There was talk of a "sanguine" youth, a "choleric" maturity (up to 40 years), a "melancholy" period (40 to 60 years) and a "phlegmatic" old age.

Melancholy therefore immediately has its place as a typical temperament. The major symptoms are fear and sadness.

Treatments are studied to restore balance and diets to maintain it. We can correct the excessive coldness of the old men by offering them a little wine, but the excessive heat of young people absolutely forbids them this drink. If the mood cannot be evacuated naturally (by the bleeding nose, urine, defecation, vomit), we can resort to remedies that will cause it (diuretic, cholagogue). Therapeutics therefore rely essentially on certain types of diet to restore the humoral balance, associated with certain drugs including a specific, hellebore (root of a pungent and bitter nauseating taste, very violent purgative). Purge is one of the oldest treatments of madness and was abandoned in the nineteenth century. Conversely, when a mood is lacking, it can be remedied by appropriate food or exercises (walking, massage).

Aristotle (384-322 before $\mathrm{BC}$ ) The melancholic temperament summarized at the time to the symptoms that go from fear to anxiety, misanthropy and constant despondency, is an idea that, once again, goes back to Hippocrates and more specifically to the problems attributed to Aristotle where it is more clearly explained.

In the famous problem, called "Problem XXX, 1" [6], Aristotle explains that there are two kinds of melancholy: natural melancholy and pathological melancholy.

This Greek philosopher associate's melancholy with imagination and therefore indirectly with genius. Melancholy is for him, a perfect oscillation between genius and madness. As a result, the great men (philosopher, artist, poet) are melancholic with a complex mixture of astonishment and skepticism. The author of this "problem" thus observes and understands this "tragic anomaly of the exceptional man, between exaltation and overwhelming depression". He wonders, "Why were all the exceptional men of the past, in philosophy, politics, poetry, or the arts, manifestly melancholy?" Dark mood is recognized for developing "the unmanageable faculties of the imagination ". Melancholy can therefore be associated with a pathology, or on the contrary, with the sign of genius, depending on what will be privileged between the illusions of imagination and creativity. According to Aristotle: "There is no genius without a grain of madness" [7]. Finally, he distinguishes two psychopathological charts. On one side, we find the quiet madness caused by an excess of cold black bile resulting in states of unconsciousness, euthymia and dysthymia. On the other side, there is the agitated madness due to an excess of hot black bile causing mania, the subjects are impulsive and angry.

Galen (129-201) The name of melancholy has been imposed on this species of madness because according to Galen, Greek physician of antiquity, the sad moral affections depend on the bile which, become black, darkens the animal spirits and makes delirious [8].

Areteo of Cappadoce (2nd century $A D$ ) The first written descriptions of a relationship between mania and melancholy are established before the Christian era by Areteo of Cappadocia. This Greek doctor insists on the character of hyper-religiosity, guilt and sacrifice of the melancholic. Hippocratic thought distinguishes several nosological entities some of which will continue: frenzy, lethargy, mania or melancholy. Frenzy and lethargy result in acute madness with fever. Mania and melancholy, meanwhile, correspond to two chronic follies without fever: mania with excitement and melancholy with depression [9].

\section{Middle ages}

From the 4th century, the Christian hermit movement will highlight the dangers of melancholy. The anchorites are Christians who decide to live in solitude and for that they retire 
to the desert to break with a society they consider in perdition. In this isolation, one of the dangers that threatens them is acedia. The acedia is, initially, a discomfort linked to the excess of deprivation which seizes the monks [10]. This term means "negligence", "grief", "indifference". By seizing this symptom, which among the desert monks is rather psychic discomfort than "evil", Christians turn it into emissions of evil and evil thoughts. It becomes the most formidable temptations in connection with the demon and the moral fault. Acedia becomes a divine punishment. It will haunt the monasteries of the West but also the secular society until the end of the Middle Ages.

\section{Renaissance $\left(16^{\text {th }}\right.$ century)}

From the 16th century, the nascent humanism will restore to honor the previous reasoning of Aristotle for which the melancholic is primarily a man of genius. Faced with questioning, with knowledge, with metaphysical reflection, man is melancholy. "The Renaissance," said Starobinski, "is the golden age of melancholy" [11]. Such an assertion may seem surprising at first. Wasn't optimism, according to the received idea, the dominant note of what is called the Renaissance? Yet it was at this same time that Luther and Machiavelli, whose credibility is proven with their contemporaries, made equally negative judgments on man. A study of melancholy - state of mind and mental illness - between 1480 and 1640 reveals the worries and fantasies of a civilization that multiple shocks since the mid-fourteenth century have thrown into a situation of "uncomfortable" " Progressing from top to bottom, religious acculturation logically spread the pessimism of the elites to the whole of society.

The discourse on melancholy was another way of recalling the limits of free will - limits imposed by both moods and planetary influences. From distant Antiquity until the $18^{\text {th }}$ century, it was considered that prolonged sadness came from a corrupt mood. The Greek doctors Hippocrates and Galen had put this explanation, taken up and clarified over the ages, in particular, by Constantine the African (died in 1087) who restored the study of Greek medicine in Italy. His De Melancholia constitutes the link, in this respect, between ancient science and Renaissance medicine. The latter takes up without notable modifications the traditional theory of the four humours, which are respectively blood, phlegm or pituite, cholera or yellow bile and the mood of melancholy - this term derived from the Greek meaning precisely "black bile".

There is, notes Ambroise Paré (died in 1590), which takes up the classifications of Galen, "a certain proportion and measure of said moods (in the blood in the general sense), which being kept gives health to the body: but if it is corrupted , it brings and causes illness ". Adequately "melancholy" is therefore essential for us. But if it becomes preponderant in the organism, this disagreement of the elements turns to our detriment. Taking into account the correspondences then admitted between, on one side, the moods and, on the other, the four elements, the direction of the winds, the ages of life, the seasons of the year, even the times of the day, we obtained with great coherence the four great human temperaments according to the predominance of this or that mood. The melancholy temperament predisposes individuals to be "sad, annoying, firm, severe and harsh, envious and shy".

\section{The classical age $\left(16^{\text {th }}-18^{\text {th }}\right.$ century)}

In the classical age stretching from the completion of the Renaissance to the end of the Enlightenment, there is a new reversal: melancholy is considered an alienation of the imagination. It must be fought with reason, irony. Melancholy becomes a disease. Mental pathology takes place in medicine with the appearance of institutions some of which will claim the specificity. There is no longer one but "some" melancholy. His representations multiply: vanities of earthly goods, vanity of knowledge, of philosophical reflection, of art itself [12].

The melancholy par excellence is a person weakened by the absence of meaning, meanings of things, emptiness. Nevertheless, it is possible to fight against this pathology by the desire to control reason.

Robert Burton (1577-1640) The "Anatomy of Melancholy" published in 1621 by Robert Burton [13], a teacher and vicar at Oxford, has a great influence on the ideas concerning this disposition of the mind. He analyzes melancholy: its causes, its symptoms, its effects, the most unexpected characteristics of these manifestations, its remedies. For him, melancholy is a disease. He refuses to believe in the existence of a possible natural and non-pathological form of melancholy, that melancholy previously evoked as a natural temperament that can lead to genius. This book constitutes an important sum of all the knowledge and theories that Burton binds to mourning.

Burton proposes to make religious melancholy a species full of melancholy. It launches the kick-off of a medicalization of religious controversies that takes all its importance following the English Civil War. The Anglican orthodox criticize these ideas and present fanatics or atheists as patients suffering from a humoral imbalance. This category of religious melancholy will end up, however, by designating, in the early eighteenth century, a certain way of practicing religion but also the kind of life of the subjects who devote their existence to religion.

In this transitional period of the passage from the Renaissance to the lights, Burton is one of the first to condemn this "melancholy fashion" that leads people to indulge in a state that may be a priori pleasant but that may lead to withdrawal on oneself and on madness.

"Among so many thousands of authors, you will find it difficult to find some whose reading will make you a little better; on the contrary, it will infect you when it should help to perfect you. Burton considered himself melancholic.

\section{Romanticism (late $18^{\text {th }}-19^{\text {th }}$ century)}

Romanticism places a point of honor on certain ideas of ancient melancholy. With the development of individualism, the sensitive man stands aside from society and exploits the resources of the fantastic, the imaginary. This romantic solitude compares itself to the melancholy position. In the 
nineteenth century, one wonders about the link between man and the world at the expense of the relationship between the divine man. The expression of melancholy develops as "evil of the century" at Musset, takes a form of boredom for Flaubert. Baudelaire, meanwhile, speaks of "spleen": "as a child, I felt in my heart two contradictory feelings: the horror of life and the ecstasy of life [14].

The trauma induced by the rejection of the Christianity of the Terror of 1793 and the fall of the Empire in 1814 founds the melancholy of the time. Great past exploits, the future of a new bourgeois France with the sole objective: enrichment. Baudelaire tries to escape artificial paradises; melancholy comes from an energy that cannot be invested and becomes a "black poison" [15]. In conclusion, artificial paradises lead to the death of the soul.

Melancholy is the hallmark of the artist of the time. It is a morbid state where we no longer support ourselves, where loneliness becomes a hell, cruelty gives way to temptations of political revolt or suicide see the madness. The melancholy inspired many artists of the time as the painter Francisco de Goya who realized after the upheaval of the war a series of painting between 1820 and 1823, including the one presented below "Saturn devouring one of his children" in 1823 ( the astrology of Antiquity having identified Saturn as the star of melancholy) [16].

Michel Foucault (1926-1984) "Madness and unreason. History of Madness in the Classical Age ", a book by Michel Foucault in 1961, changed the reading of this period [17]. The thesis of his work highlights a coincidence between two dates: on the one hand René Descartes' "Discourse on the Method" of 1637, on the other the "great confinement" resulting from the creation of the General Hospital in 1656. In comparison with the Middle Ages, where society separates and isolates lepers, the classical age displaces the object of segregation. Indeed, the fool takes the place of the leper. Leprosaria is transformed into houses of internment. According to Foucault, the date this true "break" is in 1656. From this date, one in a hundred inhabitants was interned in Paris. We would have done everything to remove the madman from the social space. As a result, classical reason would coincide with the rejection of the irrational "the fool", in the name of established rationality as a norm. "Become the shadow of reason, madness deserves only the shadow of the dungeon, where it can be ignored and forgotten." Since madness is reduced to unreason, reason have nothing to learn from the madman.

\section{Birth of modern psychiatry in the early nineteenth cen- tury}

Philippe Pinel (1745-1826) After the "great confinement" of the seventeenth century seen above, a growing population is relegated to General Hospitals (crazy, vagabonds, foolish, bad women, libertines). The increase of the population in these establishments is thus considerable and those until the circular of 1785 which will be decisive for the birth of psychiatry. "Instructions on how to govern the foolish and to work for their healing in the asylum intended for them" is a circular government where the "foolish" will benefit from a particular confinement. 1785 marks the beginning of the therapeutic asylum [18]. Indeed, this circular recommends not to sequester the insane, but to treat them in specialized institutions, subdivided into neighborhoods (quiet, violent lunatics, foolish fools, etc.). In this context, Pinel arrives at the hospital Bicêtre in 1793, where we receive the crazy estimated incurable, their living conditions are abominable [19].

Philippe Pinel, appointed doctor of the infirmary in Bicêtre, meets Jean-Baptiste Pussin "governor general of the fools" who gives him a report concerning "the state of the fools entered Bicêtre since January 1, 1784 just and including the last December 1792 "Using the observations of this nurse, Pinel begins to establish a first classification of mental illness.

Through the history of medicine, Pinel is considered a clinician and a nosography (the description of diseases). This is the beginning of medicalization of symptoms and the birth of psychiatry. It encourages the "clinical" attitude of observation and treatment of madness. It describes diseases based on the analytical method described by naturalists and anatomists and therefore less by the symptoms [20].

Pinel is presented as the liberator of the insane who will free the madmen from their chains and the founder of modern psychiatry. A new era is opening up in the reports of the mentally ill and their medical supervision. For him, the fool is not totally insane.

Through his famous "Medico-Philosophical Treatise on Insanity or Mania" 1801 whose first edition focuses on mania (the most typical and common mental illness), he explains that each abnormal symptom must lead to an organic cause. or functional. He recognizes that the causes of alienation are hereditary predispositions or secondary to external aggression (strong emotions). Pinel establishes the "moral treatment" of fools through an interpersonal relationship between the psychiatrist and the madman. If it is possible to communicate with the fool and if this exchange provides therapeutic effects, it means that the insane is not necessarily taken entirely in his madness, he keeps a distance from his madness. By this reasoning, a remnant of reason remains in him, and therefore a cure can be envisaged. In summary, the "moral treatment" is based on the one hand in the establishment of a possible curability in the madman, on the other hand in the discovery of a possible dialogue with it and finally a distance always possible madman to his own madness. It highlights a "periodic mania" altering moments of profound alteration of the patient's consciousness and moments of great lucidity. There is therefore a whole new psychiatric methodology.

1) In the second edition of his "Medico-Philosophical Treatise on Insanity" in 1809, the classification of mental illnesses is based on behavior from the lightest to the most serious. It also proposes a classification of mental illness into 4 categories.melancholy, where delirium is limited to a particular object or series objects. The emotional state or theme of delirium may be sad or cheerful and exalted. 
2) mania, where delirium is general.

3) dementia, where there is impairment of all mental faculties, generalized intellectual debility.

4) idiotism, where there is suppression of mental activity.

We can also quote William Cullen, author of the famous book "Institution of Practical Medicine", which will greatly influence Pinel by emphasizing the main role of the nervous system in the transmission of sensations and irritations [21].

Etienne Esquirol (1772-1840) Pupil of Pinel, French psychiatrist, he establishes a more precise classification of mental illnesses and specifies the diagnosis of melancholy. For him, the term melancholy defines a habitual state of sadness of certain individuals, it must be reserved for moralists and poets. Melancholy corresponds to a temperament in which the hepatic system predominates and is predisposed to fixed ideas and sadness [22]. Esquirol uses terms of "lypémanie" instead of melancholy. The word monomania is used to express a sick state where delirium is limited to a single idea. Monomania is divided into two categories:

1) maniacal monomania defining a partial delirium accompanied by an exciting or gay passion.

2) lypémanie or true melancholy qualifying a chronic delirium maintained by a sad, debilitating and oppressive passion.

With Esquirol, one observes the difficulty of the diagnosis related to the characterization of the mood which accompanies the delirium. Using the term "hypemania", he tries to differentiate the purely sickly state of melancholy from what is otherwise a style of temperament [23].

"Monomania characterized by a gay or sad, exciting and oppressive passion, producing the fixed and permanent delirium of desires and determinations relative to the character of the dominant passion, is naturally divided into monomania proper, having as a characteristic sign a partial delirium and an exciting or cheerful passion; and in monomania characterized by a partial delirium and a sad and oppressive passion. The first of these affections corresponds to maniacal melancholy, manic fury, melancholy complicated with mania. I consecrate to it the name of monomania.

\section{Second half of the $19^{\text {th }}$ century}

This period is marked by the emergence of a psychiatric clinic that moves psychiatry from paradigm (a coherent worldview model based on a definite basis) from mental illness to the paradigm of mental illness. Jean-Pierre Falret (1794-1870) finds an injury origin to madness the existence of monomania described by Pinel and Esquirol. For him, there is an alternation of mania and melancholy called "circular insanity"[24]. He developed a new form of "moral treatment" using the words of Philippe Pinel. This time, it is a "bullying", the mad must give up delirium under penalty of sanctions.
The crossroads of the late nineteenth century: 18701920

The theory of degeneration: The theory of degeneration opens a new page in the history of the evolution of ideas in mental pathology. The doctrine of degeneration is associated with the name Bénédict Augustin Morel (1809-1873) who popularized this term in 1857, the year of publication of his "Treatise on physical, intellectual and moral degenerations of the human species", then in 1860 in his Treaty of mental illnesses. Under the effect of debilitating influences of the environment, adverse social factors and negative moral factors, the individual sees his nervous system subjected to constant aggressions. The origin of these disorders constituting this mental state, according to Morel, thus finds its origin, either in affections acquired at a young age, or in heredity. He will illustrate these, citing intoxications and alcoholism, misery, malaria, etc. The latter could cause injuries that were at the root of the various mental disorders of which the person was a victim during his life. The individual thus found himself engaged in a "sickly deviation" leading to dementia [25].

Valentin Magnan (1835-1916) Valentin Magnan, meanwhile, separates the lunatics into two groups: the normal and the degenerate. The normal ones become sick, maniac, delirious or melancholic under the effect of various causes but of great intensities. In return, the degenerates present a primitively troubled mentality which, for a commonplace cause, will present great troubles. We observe in this category the lower degenerates (idiots and imbeciles) or the average ones (the morons) with weak moral and intellectual faculties and marked brain lesions, and the higher degenerates with a disharmonious moral and intellectual development explained by a dissociation of the centers: psychic and motor [26].

Emile Kraepelin (1856-1926) Emile Kraepelin is a prominent clinician from a period when German psychiatry is at its peak. From his point of view, the essential lies in the careful observation and the clinic [27]. In his "Introduction to Clinical Psychiatry" (1907), he carries out a varied classification of depressive states. At the head of the chapters, one finds successively: melancholy, depressive circular states, catatonic stupor, manic-depressive mixed states, catatonic excitation ... The categories multiplied according to the alternation or the permanence of the episodes and according to their duration [28]. His definition of melancholy brings together the different elements that psychiatry of the time had noticed: "The syndrome of melancholy is characterized by the insensitive development of anxious depression, to which delirious conceptions are joined in very variable proportions" [29]. The most common are guilt ideas. At other times, hypochondriac ideas dominate the picture. Finally, it may be the fear of becoming poor, starving, going to jail, being judged, etc. Gradually anxiety becomes so great that the sick want to die, and very frequently indeed, they commit suicide. » It brings together, on the one hand, the vast majority of delusional disorders under the name "early dementia", a term that emphasizes a terminal disturbance of intellectual faculties. On the other hand, and symmetrically, he creates a set that he will call "manic-depressive illness", whose fundamental disorder does not concern the intellectual but 
emotional sphere. Kraepelin bases his nosography on the great dichotomy of the psychic life between thought and intellectual feeling and emotion, representations and affections. We can say that the discovery, 50 years later, of two major classes of psychotropic drugs, neuroleptics and antidepressants, some active on psychoses, others on depressions, confirms, so to speak, the Kraepelin dichotomy, even if all psychiatrists agree that there is no mood disorder without thought disorder and vice versa. In fact, the depressed person is not only sad, but also expresses a pessimistic view of himself and the world, and the delusional person has not only a disorder of thought, but also develops a certain number of affective states. relative or not to his ideas. He established the great nosological frameworks and introduced the conceptual scheme, still used today, of classical psychiatry. Melancholia ends up being treated as a real disease outside literary and philosophical considerations, and where it is situated between manic-depressive madness and manicdepressive psychosis.

What intrigues in these definitions or summary presentations of the main manifestations of melancholy is the non-systematic listing of symptoms that the syndrome is not supposed to distinguish itself from. One has the impression of a complete disorder in the succession of marks of behavior named not Kraepelin because one does not see according to which psychological criterion, they are structured.

\section{Twentieth century}

The transformation of melancholy first into lypémanie, then into madness or manic-depressive psychosis, endogenous melancholy or simply depression, signals such an evolution which implies, in particular, the break-up in the nineteenth century (when psychiatry is born), ancient concept of melancholy in several names of mental illnesses some of which no longer remember. At the crossroads of the nineteenth and twentieth century, the status of melancholy becomes complex. The word is avoided by the writers who really feel it, abandoned by the psychiatrists, but still used in the current language or it designates a state of mind, a sentimental disposition, a mixture of reverie and comfortable sadness. On the other hand, melancholy enters psychoanalysis with the famous contribution of Sigmund Freud.

Sigmund Freud (1856-1939): the psychoanalytic revolution. Sigmund. Freud, meets several important personalities for the development of psychoanalysis, of which he is the principal theoretician [30]. This Viennese doctor brings together a generation of psychotherapists who, little by little, develop psychoanalysis. He relies on elements of his personal life to write his works, which contributed to the advance of psychoanalysis. "A man like me cannot live without a dada, without a passion, without a tyrant ... This tyrant, I found him and enslaved him body and soul, his name is psychology.

A little outside the nosography (description and systematic classification) of the time, Freud describes melancholy as "subjective fate". Inspired by a paper presented by Karl Abraham at the Third Congress of Psychoanalysis in 1911, he proposes an analogy between melancholy and the work of mourning. In short, the self identifies with the lost object to the point of losing itself in the infinite despair of an irremediable nothingness " In 1915, he published "Mourning and Melancholia" [31], founding text for psychoanalysis of the theory of melancholy. In fact, to a certain extent, what happens in the melancholy crisis is entirely like the loss suffered by the death of a loved one. A painful state of mind, a lack of interest in the outside world as well as the inability to choose a new object of love and in general the abandonment of any social activity characterizes the mourning. With one exception, the loss to which the melancholic reacts is unconscious, and is not directly related to a real loss as in mourning. The only difference between mourning and melancholy is thus manifested by the presence, in the last, of a deprecating attitude towards one's own self, which goes as far as "delirious" forms of violence, among which suicide remains the most radical. This trait manifests itself through the discourse of the subject suffering from depression and is most often realized by complaints that the analyst must not reject. For Freud, the melancholy has made the objectual disinvestment, but the quantity of libido remains intact and affixed to the ego, which then becomes the lost object. The melancholy thus regresses to narcissistic identification, becoming its own object, and privileging the side of hatred: it can explain self-reproaches.

Psychoanalysts Sigmund Freud, Karl Abraham and Melanie Klein define depression as the result of a psychic conflict (oedipal or narcissistic) and not as the passive carrier of a disease to heal. For Freud, it is a question of resolving the repressed conflict by analyzing the resistances, so that the patient finds the freedom to decide for this or that thing [32].

\section{Symptoms of depression nowadays}

Nowadays the diagnostic criteria for the major depressive episode are listed in ICD-10 (International Classification of Diseases, 10th Edition) [33] and the DSM-5 (Diagnostic and Statistical Manual, 5th Edition) with symptoms ranging from the mild to moderate depressive episode and the so-called severe episode, published on May 18, 2013 by the American Association of Psychiatry.

\section{Symptoms of depression (ICD10)}

1. Depressed mood

2. Loss of interest or pleasure

3. Fatigue or loss of energy At least 2 of the symptoms all day, almost every day. Other symptoms /Criteria

Presence of at least 4 symptoms (out of a total of 7):

4. Significant weight loss or gain

5. Insomnia or hypersomnia

6. Agitation or psychomotor retardation

7. Fatigue or loss of energy

8. Feeling of worthlessness or excessive guilt or inappropriate (which may be delusional) 


\section{Decreased ability to think or to focus}

10. Recurring thoughts of death, recurrent suicidal thoughts without specific plan or suicide attempt or specific plan for committing suicide

Presence of at least 2 minor criteria

(out of a total of 7):

4. Inappetence, weight loss

5. Sleep disturbances

6. Lower self-esteem and self-confidence

7. Gloomy, pessimistic attitude towards the future

8. Feeling of guilt / worthlessness

9. Reduced concentration / attention

10. Suicidal thoughts

\section{The different types of depression in the 21st century [34]}

Dysthymia: To be able to speak of a diagnosis of "dysthymia", you must observe at least two of the symptoms of depression. It is a very common form of depression. Minor depression is depression that can affect anyone. We talk about depression, but it is less severe than other forms of depression. The symptoms of depression that manifest with this form of depression are the common symptoms of depression. You can find these symptoms in the symptoms of depression section or in the main article on depression. The maximum number of symptoms of depression observed for this form of depression can amount to 4 symptoms. If this criterion is exceeded, we speak of a more serious form of depression. Dysthymia is therefore a mild form of depression because there are only a limited number of symptoms of depression. This is not to say that the person's subjective suffering cannot be treated as much or at all. Although this is a milder form of depression, you can effectively combat your suffering and symptoms of depression. The milder the symptoms, the sooner you seek treatment, the sooner you will see the effect of this treatment.

Major depression: In order to speak of a diagnosis of major depression, one should observe between 5 and 9 symptoms of depression. This form of depression is also common. It may be one of the lesser known forms of depression when it is often encountered. Research indicates that more than $17 \%$ of the world's population suffers from major depression during their lifetime (D. G Blazer and R. C. Kessler, 1994). The symptoms that should be observed for this form of depression are the common symptoms that are spoken of in the event of depression. You can find these symptoms in the symptoms of depression section or in the main article on depression.

When it comes to major depression, the known symptoms of depression appear for a single period for at least two weeks. A major depression is therefore a single period which can last from several weeks to several years. If more than one episode occurs, this is called another form of depression.
Chronic depression: In the case of chronic depression, the symptoms of depression appear repeatedly. This means that you are going through several depressive periods, unlike major depression. This form of depression belongs to the encompassing forms of depression. Chronic depression, however, is a lesser-known form of depression, as the most well-known forms of depression only occur once. You can find common symptoms of depression also for this kind of depression. Between periods of depression, there must be a period of at least two months. During these two months, you cannot experience any symptoms of depression, otherwise it is called persistent depression.

Chronic depression is a period in which you have no symptoms of depression. After these two months, you can go through a depressed period again with the associated symptoms.

Bipolar depression: To be able to speak of a diagnosis of bipolar depression, depressive periods must alternate with periods of high euphoria or agitation. Euphoric periods are also called manic periods. During these periods, the patient feels "king of the world" and is quickly irritated. Many people also do irrational things during manic times, such as making purchases that they cannot afford. After this manic period, the client relapses into a depressive period. During this depressive period, the client experiences several symptoms of depression in an overwhelming climate. We will therefore feel constantly sullen and depressed. These depressive periods generally last longer than manic periods. In bipolar disorder 2 the manic episodes are replaced by hypomania [35].

Other forms of depression: There are also fewer common forms of depression, such as postnatal depression [36], a form of depression that occurs after the birth of a child, seasonal depression, a type of depression that occurs primarily during a particular season, etc. These forms of depression can be linked to certain hormones, such as in the case of postnatal depression, or to the perception of light, as in the case of seasonal depression. You may then feel depressed in winter, for example, because you are not getting enough sunlight.

\section{The revolution of neurology and neuroscience}

After the revolution of nineteenth-century brainwashing with the role played by the hypothalamus, the regulating center of the needs and orders of the great metabolism, we can cite Von Economo, Vogt and Brodman, who describe the architecture of the brain by exploring the motor areas [37].

At the beginning of the 2oth century, the first truly effective therapies were shock methods such as insulin treatments or electroconvulsive therapy (ECT).

It is also the successes of pharmacology that have brought depression to its current dimension. If we do not know enough how to define it, we at least try to cure it. Henri Laborit, Pierre Deniker and Jean Delay discover the first neuroleptics in Paris in 1952 , this discovery inaugurates the era of commercialization of modern psychotropic drugs. Roland Kuhn, a Swiss psychiatrist, close to psychoanalytic circles who in 1956, elaborated the antidepressant effects of imipramine [38]. 
The scientists are based on the study of chemical mediators whose action is at the level of neuronal synapses: acetylcholine, norepinephrine, adrenaline and dopamine, whose dysregulation (excess or depletion) could be the cause of a certain number of symptoms. psychiatric, from depression to psychotic symptoms.

These first antidepressants were prescribed in the hospital mainly by psychiatrists for fear of side effects. The understanding of the brain has led to the discovery of more effective biological therapies and especially less disabling. From the late 1980s, newer antidepressants came on the market with fewer side effects. In parallel, the development of cognitive psychology will join the progression of brain imaging techniques to gradually build the wide field of neuroscience.

\section{Nowadays}

It is clear that the great currents of contemporary psychiatry, at the origin of models as different as psychoanalysis or neuroscience, sometimes complement each other, often oppose or ultimately ignore each other.

Thus, on the psychiatric level, the etiological data, from clinical studies and follow-up, of investigations on cohorts of individuals or groups of individuals, reiterated over a given period of time to which studies of pharmaceutical laboratories, have made it possible to highlight more precisely today the so-called mood disorders, or of syndromes much more known under the term depressive disorders.

\section{Brain plasticity and depression}

The brain is constantly being remodeled [39]. For the links between depression, plasticity and recent events, we must briefly talk about the mode of action of antidepressants, which are increasingly believed to have cerebral neurotrophic effects. This means that antidepressants activate the secretion in the brain of molecules, which are peptides, whose properties are to make neurons grow (or their extensions). This would imply that there is some kind of atrophy or agenesis of certain neurons, or neuronal extensions, in the brain of the depressed, a hypothesis that not everyone shares (some researchers even believe that if antidepressants stimulate secretion neurotrophic factors, that's because they themselves have neurotoxic properties). Electroshock also stimulates the production of neurotrophic factors, as do certain mood stabilizers, but it would be wrong to say that the neurotrophic theory of depression has now completely found its mark. There are therefore certainly in depression phenomena which fall within the framework of what is called recent plasticity, but we are always looking, on the qualitative level, for the plastic mechanisms which make that in the depressed neurotransmitters do not more optimally perform their role as activators or coordinators of the various brain structures involved in stress, and which make antidepressants capable of restoring neurotransmitters this capacity by enhancing their activity.

The links between old events and plasticity are the subject of much research. There are links between experiences of separation, or social isolation, at different stages of life, and the development of neurotransmitter systems, expression of peptides (neurotrophics and opiates), the activity of the hypothalamic axis -cortico-adrenal (HPA) and the sensitivity of central receptors to corticosteroids. It is certain that individual history, and more precisely traumatic history, that of stresses of different types, leaves imprints in the brain, and we are able today to recognize a certain number of these imprints in animal experimentation.

\section{References}

1. Hippocrates the Aphorisms of Hippocrates: With a Translation into Latin and English, Anonymous, Andesite Press 2017. Link: https://bit.ly/2YxFT2d

2. Jackson WA (2001) A short guide to humoral medicine. Trends Pharmacol Sci 22: 487-489. Link: https://bit.ly/3b84soQ

3. Chiappelli F, Prolo P, Cajulis OS (2011) Evidence-based research in complementary and alternative medicine I: history. 11: 116-117.

4. Baudelaire C, Howard R (1983) Les Fleurs Du Mal. David R. Godine Publisher xxv. Link: https://bit.ly/3baxOhr

5. Jones WHS (1868) Hippocrates Collected Works I. Cambridge: Harvard University Press.

6. Gatrall JJA (2003) The Paradox of Melancholy Insight: Reading the Medical Subtext in Chekhov's "A Boring Story". Slavic Review 62: 258-277. Link: https://bit.ly/3b7JvdV

7. Flannery KL (2013) Action and Character According to Aristotle: The Logic of the Moral Life. The Catholic University of America Press.

8. Telles-Correia D, Marques JG (2015) Melancholia before the twentieth century: fear and sorrow or partial insanity? Front Psychol 6: 81. Link: https://bit.ly/3b3H2AX

9. Zaccagni M, Colombo PP, Frana A (2008) History of bipolar disorder: From Areteo of Cappadocia to DSM-IV and bipolar spectrum Rivista di Psichiatria 43: 348-360. Link: https://bit.ly/3djY3bU

10. Sands Wise J (2013) Diagnosing Acedia and Its Spiritual Neighbors. Christian reflexions: Acedia Baylor University 56-91. Link: https://bit.ly/2YAoo13

11. Starobinski J (2012) L'encre de la mélancolie. SEUIL Ed. 672. Link: https://bit.ly/3fwDVVU

12. Barr T (2019) Without Apparent Occasion: Melancholy and the Problem of Motive in Baroque England. Thesis University of Pittsburgh. Link: https://bit.ly/2WwOHVO

13. Burton R Anatomy of Melancholy 1621, Edited by Angus Gotland. Penguin 1424. Link: https://bit.ly/2SEdcg4

14. Wolfson SJ (2014) Romanticism \& Gender \& Melancholy. Studies in Romanticism, New directions in romantism and gender: Essays in honor of Anne K. Mellor (fall 2014) 53: 435-456. Link: https://bit.ly/2SDzIG0

15. Kaplan EK (2019) Baudelaire through Kierkegaard in Thinking Poetry Philosophical Approaches to Nineteenth-Century French Poetry ed Joseph Acquisto 9-24.

16. Nordstrom F (1962) Goya, Saturn and Melancholy: Studies in the Art of Goya (Figure; Uppsala Studies in the History of Art). Stockholm/Goteborg/Uppsala, Almqvist \& WiCell 239: 109. Link: https://bit.ly/2KZ1IVR

17. Foucault M (1961) History of Madness 2006. London/New York: Routledge 725

18. Cousins M, Hussain A (1984) The Asylum. In: Michel Foucault. Contemporary Social Theory. Palgrave, London 106-140. Link: https://bit.ly/2WuJIT1 
19. Wallace ER, Gash J (2010) History of Psychiatry and Medical Psychology: With an Epilogue on Psychiatry and the Mind-Body Relation. Springer Science Business Media 862. Link: https://bit.ly/2YCVA8q

20. Weiner D (1992) Philippe Panel's "Memoir on Madness" of December 11, 1794 a fundamental text of modern psychiatry. Am J Psychiatry 149: 725-732.

21. Wolf JC (2016) The Learned Medicine of Dr. William Cullen (1710 1790). CreateSpace Independent Publishing Platform 490. Link: https://bit.ly/3fqE2SW

22. Huertas R (2008) Between doctrine and clinical practice: nosography and semiology in the work of Jean-Etienne-Dominique Esquirol (1772-1840). Hist Psychiatry 19: 123-140. Link: https://bit.ly/2A2ArKv

23. Huertas R (2014) Subjectivity in clinical practice: on the origins of psychiatric semiology in early French alienism. Hist Psychiatry 25: 459-467. Link: https://bit.ly/2W3Isao

24. Pichot P (2004) Circular insanity 150 years on. Bull Accad Natl Med 188: 275 284. Link: https://bit.ly/35AkvL9

25. Schuster JP, Le Strat Y, Krushinski V, Berkoff N (2014) Benedict Augustin Morel (1809-1873) Limos in M Acta Neuropsychiatric 2011. 23: 35-36

26. Dowbiggin I (1996) Back to the Future: Valentin Magnan, French Psychiatry, and the Classification of Mental Diseases, 1885-1925. Soc Hist Med 9: 383 408. Link: https://bit.ly/2SG2shr

27. Andreasen NC (1994) Emil Kraepelin, 1856-1926. Am J Psychiatry 151: 428 Link: https://bit.ly/2L2K125

28. Memoirs KE, Peters HHG (2019) Ploog. Springer Nature 270.

29. Kraepelin E (1990) Psychiatrie. Ein Lehrbuch für Studierende und Ärzte. 8. Auflage. Vol 1. Leipzig, Germany: Barth 348ff.

30. Edelson M (1984) Hypothesis and Evidence in Psychoanalysis. University of Chicago Press. Link: https://bit.ly/3c7q5am
31. Freud S (1917) Mourning and Melancholia. The Standard Edition of the Complete Psychological Works of Sigmund Freud, Volume XIV (1914-1916) On the History of the Psycho-Analytic Movement, Papers on Metapsychology and Other Works. 237-258. Link: https://bit.ly/2xEYLkM

32. Zaleznik A (2019) Executive's Guide to Understanding People: How Freudian Theory Can Turn Good Executives into Better Leaders. Springer Nature 187. Link: https://bit.ly/2YALbdd

33. The ICD-10 Classification of Mental and Behavioural Disorders. WHO. Link https://bit.ly/3dlH7Bw

34. MacQueen G, Santaguida P, Keshavarz H, Jaworska N, Levine M, et al. (2017) Systematic Review of Clinical Practice Guidelines for Failed Antidepressant Treatment Response in Major Depressive Disorder, Dysthymia, and Subthreshold Depression in Adults. Can J Psychiatry 62: 11-23. Link: https://bit.ly/3b4ZY2t

35. Bourin M (2017) Bipolar disorder is now a more common disease to be treated Theranostics Brain Disorder. 1

36. Bourin M (2018) Postpartum depression: An overview. Arch Depress Anxiety 4: 065-067. Link: https://bit.ly/3daW3Tc

37. Zilles K (2018) Brodmann: a pioneer of human brain mapping-his impact on concepts of cortical organization. Brain 141: 3262-3278. Link: https://bit.ly/2WsdnMO

38. Hillhouse TM, Porter JH (2015) A brief history of the development of antidepressant drugs: from monoamines to glutamate. Exp Clin Psychopharmacol 23: 1-21. Link: https://bit.ly/2YxC11b

39. Liu W, Ge T, Leng Y, Pan Z, Fan J, et al. (2017) The Role of Neural Plasticity in Depression: From Hippocampus to Prefrontal Cortex. Neural Plast 2017 6871089. Link: https://bit.ly/2z7qgUp

\section{Discover a bigger Impact and Visibility of your article publication with}

Peertechz Publications

\section{Highlights}

* Signatory publisher of ORCID

* Signatory Publisher of DORA (San Francisco Declaration on Research Assessment)

* Articles archived in worlds' renowned service providers such as Portico, CNKI, AGRIS, TDNet, Base (Bielefeld University Library), CrossRef, Scilit, J-Gate etc.

* Journals indexed in ICMJE, SHERPA/ROMEO, Google Scholar etc.

* OAI-PMH (Open Archives Initiative Protocol for Metadata Harvesting)

* Dedicated Editorial Board for every journal

* Accurate and rapid peer-review process

* Increased citations of published articles through promotions

* Reduced timeline for article publication

Submit your articles and experience a new surge in publication services (https://www.peertechz.com/submission).

Peertechz journals wishes everlasting success in your every endeavours.

Copyright: ( 2020 Bourin M. This is an open-access article distributed under the terms of the Creative Commons Attribution License, which permits unrestricted use, distribution, and reproduction in any medium, provided the original author and source are credited. 